\title{
METODE BERMAIN PERAN SEBAGAI UPAYA MENINGKATKAN \\ KEMAMPUAN BERBAHASA JAWA PADA PESERTA DIDIK KELAS 6 SD 5 HADIPOLO KECAMATAN JEKULO KABUPATEN KUDUS SEMESTER 1 TAHUN PELAJARAN 2014/2015
}

\author{
Supriyati \\ SD 5 Hadipolo \\ email: supriyatispd63.gmail.com
}

\begin{abstract}
Goals to be achieved in this research is to improve: 1) proficiency in Java by implementing the use of methods play a role; 2) motivation of learners in learning, that liveliness, interest, desire of students to learn the Java language by applying the method to play the role properly. This research is a classroom action research (CAR) conducted in SD 5 Hadipolo Jekulo District of Kudus, with the subject of the learners Class 6 SD 5 Hadipolo Jekulo District of Kudus Semester 1 Academic Year 2014/2015. Number of students there are 19, with details of 8 men and 11 women. As for who becomes the object of research is learning to speak the language Java. The research process carried out in three cycles that include four stages, namely the planning phase, the implementation phase, the stage of observation, as well as the stage of analysis and reflection. Based on the results of the research, there is an increase in the quality of learning both the process and the results speak Javanese language learner classes Class 6 SD 5 Hadipolo Jekulo District of Kudus Semester 1 Academic Year 2014/2015. Improving the quality of the learning process is characterized by increasing: 1) the number of quality students who are active in apersepsi activities and in learning activities; 2) the number of learners who are interested and motivated in learning to speak in Javanese; and 3) the number of learners who have been able to talk to the Java language in accordance with the upload-ungguh with the correct technique using methods play a role. Java language research results by the method of learning to play a role in the increased interest of $57.9 \%$ (31.58\% to $89.48 \%$ ), courage $68.42 \%$ (26.32\% to $94.74 \%), 57.90$ roles $\%$ (31.58\% to $89.48 \%)$, the ability of $78.95 \%(10.53 \%$ to $89.48 \%)$. It can be concluded that the interests, the courage, the role, as well as the Java language proficiency of learners can be increased through method of playing a role. As effective measures undertaken by the researchers to optimize these methods, among others: 1) divides the learners in groups based differences in the level of ability to speak in Javanese; 2) provide opportunities for learners to practice speaking the Java language through methods play a role; 3) integrate the Java language speaking skills with other language skills such as listening, reading, and writing; and 4) applying the Java language spoken in art activities in the school environment is particularly suitable learners experience gained during the study. Fundamental principle of this method is to know, to practice, apply, demonstrate, so that learners actualize speak Javanese correctly.
\end{abstract}

Keywords: Interest, courage, roles, capabilities Java language, methods play a role. 


\begin{abstract}
ABSTRAK
Tujuan yang hendak dicapai dalam penelitian ini adalah untuk meningkatkan : 1) kemampuan berbahasa Jawa dengan menerapkan penggunaan metode bermain peran; 2) motivasi peserta didik dalam pembelajaran, yaitu keaktifan, ketertarikan, keinginan peserta didik untuk belajar bahasa Jawa dengan menerapkan metode bermain peran dengan benar. Penelitian ini merupakan penelitian tindakan kelas (PTK) yang dilakukan di SD 5 Hadipolo Kecamatan Jekulo Kabupaten Kudus, dengan subjek para peserta didik Kelas 6 SD 5 Hadipolo Kecamatan Jekulo Kabupaten Kudus Semester 1 Tahun Pelajaran 2014/2015. Jumlah peserta didik ada 19, dengan rincian 8 laki-laki dan 11 perempuan. Adapun yang menjadi objek penelitian adalah pembelajaran berbicara dengan berbahasa Jawa. Proses penelitian dilaksanakan dalam tiga siklus yang meliputi empat tahapan, yaitu tahap perencanaan, tahap pelaksanaan, tahap observasi, serta tahap analisis dan refleksi. Berdasarkan hasil penelitian dapat disimpulkan terdapat peningkatan kualitas pembelajaran baik proses maupun hasil berbicara berbahasa Jawa pada peserta didik kelas Kelas 6 SD 5 Hadipolo Kecamatan Jekulo Kabupaten Kudus Semester 1 Tahun Pelajaran 2014/2015. Peningkatan kualitas proses pembelajaran tersebut ditandai dengan meningkatnya: 1) jumlah kualitas peserta didik yang aktif dalam kegiatan apersepsi maupun dalam kegiatan pembelajaran; 2) jumlah peserta didik yang tertarik dan termotivasi dalam kegiatan pembelajaran berbicara berbahasa Jawa; dan 3) jumlah peserta didik yang sudah mampu berbicara dengan bahasa Jawa sesuai dengan unggahungguh dengan teknik yang benar dengan menggunakan metode bermain peran. Hasil penelitian berbahasa Jawa dengan metode bermain peran dalam pembelajaran terjadi peningkatan minat 57,9\% (31,58\% menjadi 89,48\%), keberanian $68,42 \% \quad(26,32 \%$ menjadi $94,74 \%$ ), peran $57,90 \%$ (31,58\% menjadi 89,48\%), kemampuan $78,95 \%$ (10,53\% menjadi 89,48\%).Dengan demikian dapat disimpulkan bahwa minat, keberanian, peran, serta kemampuan berbahasa Jawa peserta didik dapat ditingkatkan melalui metode bermain peran. Adapun langkah-langkah efektif yang dilakukan oleh peneliti untuk mengoptimalkan metode ini, antara lain: 1) membagi peserta didik secara berkelompok yang didasarkan perbedaan tingkat kemampuan berbicara berbahasa Jawa; 2) memberi kesempatan kepada peserta didik untuk berlatih berbicara berbahasa Jawa melalui metode bermain peran; 3) mengintegrasikan keterampilan berbicara berbahasa Jawa dengan keterampilan berbahasa lainnya, seperti menyimak, membaca, dan menulis; dan 4) mengaplikasikan berbicara berbahasa Jawa dalam kegiatan seni di lingkungan sekolah khususnya sesuai pengalaman yang didapat peserta didik selama penelitian. Prinsip pokok pada metode ini adalah mengetahui, berlatih, menerapkan, memeragakan, sehingga peserta didik mengaktualisasikan berbicara berbahasa Jawa dengan benar.
\end{abstract}

Kata kunci : Minat, keberanian, peran, kemampuan berbahasa Jawa,metode bermain peran.

\section{PENDAHULUAN}

Penggunaan bahasa Jawa di kalangan pelajar pada saat ini banyak yang kurang memperhatikan unggah ungguh. Mereka berbicara dengan rekan seusianya maupun kepada yang lebih tua umurnya tidak membedakan, yaitu penggunaan ragam ngoko. Beberapa hal yang menjadi penyebab menurunnya kemampuan micara Jawa siswa, antara lain; (1) pengaruh arus modernisasi; (2) tuntutan penggunaan bahasa nasional maupun bahasa internasional; (3) lingkungan pergaulan siswa baik dalam keluarga, sekolah, maupun masyarakat 
kurang mendukung; (4) pembelajaran bahasa di sekolah yang belum maksimal.

Salah satu bukti adalah kemampuan berbahasa Jawa di kalangan siswa-siswa kelas 6 SD 5 Hadipolo Kecamatan Jekulo Kabupaten Kudus semester 1 tahun pelajaran 2014/2015. Sebagaian besar siswa mendapatkan nilai yang kurang memuaskan dalam aspek kemampuan berbicara/micara Jawa. 75\% siswa belum mampu berbicara Jawa sesuai dengan standar ketuntasan belajar. Siswa mengalami kesulitan dalam menerapkan unggah-ungguh bahasa Jawa secara tepat baik kepada orang yang lebih tua maupun kepada rekan sejawatnya.

Berbagai upaya telah dilakukan dalam rangka meningkatkan kemampuan berbahasa Jawa siswa, terutama dalam pembelajaran bahasa Jawa di kelas 6 SD 5 Hadipolo Kecamatan Jekulo Kabupaten Kudus semester 1 tahun pelajaran 2014/2015, salah satunya adalah meningkatkan kemampuan bebahasa Jawa siswa melalui metode bermain peran (role playing).

Dari latar belakang masalah di atas, dapat diidentifikasi permasalahan sebagai berikut : 1)kemampuan Berbahasa Jawa peserta didik kelas 6 SD 5 Hadipolo Kecamatan Jekulo Kabupaten Kudus semester 1 tahun pelajaran 2014/2015 rendah; 2) perlu dicari hal-hal yang menyebabkan Kemampuan Berbahasa peserta didik kelas 6 SD 5 Hadipolo Kecamatan Jekulo Kabupaten Kudus semester 1 tahun pelajaran 2014/2015 rendah; 3) perlu digunakan cara meningkatkan Kemampuan Berbahasa peserta didik kelas 6 SD 5 Hadipolo Kecamatan Jekulo Kabupaten Kudus semester 1 tahun pelajaran 2014/2015.

Berdasarkan latar belakang dan identifikasi masalah di atas, maka dapat dirumuskan beberapa masalah sebagai berikut :1) bagaimanakah proses pembelajaran kemampuan berbahasa dengan metode bermain peran peserta didik kelas 6 SD 5 Hadipolo Kecamatan
Jekulo Kabupaten Kudus semester 1 tahun pelajaran 2014/2015; 2) seberapa banyak peningkatan kemampuan berbahasa dengan metode bermain peran peserta didik kelas 6 SD 5 Hadipolo Kecamatan Jekulo Kabupaten Kudus semester 1 tahun pelajaran 2014/2015; 3) bagaimanakah perubahan perilaku kemampuan berbahasa dengan metode bermain peran peserta didik kelas 6 SD 5 Hadipolo Kecamatan Jekulo Kabupaten Kudus semester 1 tahun pelajaran 2014/2015?

Sesuai dengan rumusan masalah yang telah ditetapkan, penelitian ini dilakukan dengan tujuan untuk meningkatkan keterampilan berbicara berbahasa Jawa siswa kelas kelas 6 SD 5 Hadipolo Kecamatan Jekulo Kabupaten Kudus semester 1 tahun pelajaran 2014/2015 melalui penggunaan metode bermain peran dalam kegiatan pembelajaran. Secara khusus, penelitian ini bertujuan sebagai berikut :1) mendeskripsi proses pembelajaran kemampuan berbahasa dengan metode bermain peran peserta didik kelas 6 SD 5 Hadipolo Kecamatan Jekulo Kabupaten Kudus semester 1 tahun pelajaran 2014/2015, 2) mendeskripsi peningkatan kemampuan berbahasa dengan metode bermain peran peserta didik kelas 6 SD 5 Hadipolo Kecamatan Jekulo Kabupaten Kudus semester 1 tahun pelajaran 2014/2015, dan 3) mengidentifikasi perubahan perilaku kemampuan berbahasa dengan metode bermain peran peserta didik kelas 6 SD 5 Hadipolo Kecamatan Jekulo Kabupaten Kudus semester 1 tahun pelajaran 2014/2015.

Hasil penelitian ini diharapkan dapat menambah khasanah ilmu pengetahuan yang terkait dengan proses pembelajaran untuk mengembangkan kemampuan Berbahasa Jawa pada siswa kelas 6 SD 5 Hadipolo Kecamatan Jekulo Kabupaten Kudus semester 1 tahun 
pelajaran 2014/2015 dengan metode bermain peran.

\section{LANDASAN TEORETIS DAN HIPOTESIS TINDAKAN}

Teknik bermain peran adalah teknik kegiatan pembelajaran yang menekankan pada kemampuan penampilan peserta didik untuk memerankan status dan fungsi pihak-pihak lain yang terdapat dalam kehidupan nyata. Dengan bermain peran ini diharapkan peserta didik memperoleh pengalaman yang diperankan oleh pihak-pihak lain. Teknik ini juga untuk merangsang pendapat peserta didik dan menemukan kesepakatan bersama tentang ketepatan, kekurangan, dan pengembangan peranperan yang dialami atau diamatinya (Sudjana, 2005: 134).

Teknik bermain peran adalah cara pembelajaran dengan permainan yang efektif, meningkatkan kemampuan kerja sama dengan kelompok, dan diharapkan dengan metode ini, minat, motivasi, peran serta siswa dalam belajar juga akan meningkat.

Langkah-langkah pelaksanaan teknik bermain peran, meliputi: (1) guru menyusun/menyiapkan skema yang akan ditampilkan, (2) menunjukkan beberapa siswa untuk mempelajari skenario dua hari sebelum kegiatan belajar mengajar, (3) guru membentuk kelompok dengan beberapa anggota, (4) memberikan penjelasan tentang tujuan yang ingin dicapai dalam KBM, (5) memanggil para siswa yang sudah ditunjuk untuk memerankan skenario yang sudah siapkan, (6) masing-masing siswa duduk dikelompoknya sambil memperhatikan mengamati skenario yang sedang diperagakan, (7) setelah selesai dipentaskan, masing-masing siswa diberikan kertas sebagai lembar kerja untuk membahas, (8) masing-masing kelompok menyampaikan hasil kesimpulannya, (9) guru memberikan kesimpulan secara umum, dan evaluasi.
Sedangkan Sudjana (2005: 135136) memberikan langkah-langkah dalam penggunaan bermain peran, yaitu; (1) pendidik dan peserta didik menyiapkan bahan belajar berupa topik yang akan dibahas; (2) pendidik dan peserta didik mengidentifikasi dan menetapkan peranperan berdasarkan kedudukan dan tugas masing-masing; (3) pendidik membantu peserta didik untuk meyiapkan tempat, waktu, dan alat-alat yang digunakan; (4) pendidik membantu peserta didik untuk melaksanakan permainan dengan: (a) menjelaskan tujuan dan langkah-angkah bermain peran , (b) peserta didik dibagi kelompok bermain peran dan kelompok pengamat, (c) menjelaskan tugas masingmasing kelompok; (5) pendidik dan peserta didik membahas hasil pengamatan dan melakukan penilaian terhadap proses dan hasil penggunaan teknik ini.

Keunggulan teknik ini adalah (1) menarik perhatian peserta didik; (2) teknik dapat dilakukan dalam kelompok besar ataupun kecil; (3) dapat membantu peserta didik dalam memahami pengalaman orang lain; (4) dapat membantu peserta didik untuk menganalisis dan memahami situasi serta memikirkan masalah yang terjadi dalam bermain peran; (5) menumbuhkan rasa percaya diri. Sedangkan kelemahannya adalah : (1) kemungkinan peserta didik ada yang tidak menyukai permainan peran tertentu; (2) lebih menekankan pada masalah dari pada terhadap peran; (3) mungkin akan kesulitan dalam menyesuaikan dalam peran tertentu; (4) membutuhkan waktu lama; (5) terbatas pada beberapa situasi kegiatan belajar.

Menurut Widada (1993: 38-39) fungsi bahasa Jawa bagi masyarakat jawa ada dua macam, yaitu fungsi linguistik dan fungsi budaya. Fungsi linguistik adalah bahasa Jawa dipakai sebagai alat komunikasi masyarakat dalam kehidupan sehari-hari. Bahasa Jawa itu, antara lain, dipakai untuk menyampaikan gagasan atau pikiran kepada orang lain dan 
menyampaikan perasaan tertentu pada orang lain. Sehingga fungsi linguistik adalah untuk kepentingan praktis, sabagai sarana komunikasi masyarakat Jawa.

Dalam fungsi budaya, bahasa Jawa digunakan sebagai; (1) sarana pengungkap kehalusan dan kelembutan cipta, rasa, dan karsa; (2) sarana pemelihara etika dan estetika; (3) sebagai filter pengaruh budaya asing; dan (4) sebagai sarana pewarisan nilai-nilai luhur.

Sedangkan menurut Nababan, (1986: 38) menyatakan ada tiga fungsi bahasa, yaitu (1) sarana perkembangan kebudayaan, (2) jalur penerus kebudayaan, dan (3) inventarisasi ciri-ciri kebudayaan. Dalam hal ini bahasa Jawa sebagai salah satu bahasa daerah di Indonesia selain berfungsi sebagai alat komunikasi dalam etnik Jawa, juga sebagai sarana pengembang dan pengungkap seni tradisi Jawa.

Menurut Halim (dalam Sukardi, 1993: 68), bahasa Jawa, di samping bahasa Indonesia, dipergunakan sebagai bahasa perhubungan intradaerah (Jawa) di wilayah Indonesia. Dalam hubungan dengan kedudukan bahasa Indonesia sebagai bahasa nasional, bahasa Jawa sebagai bahasa daerah berfungsi sebagai (1) lambang kebanggaan daerah, (2) lambang identitas daerah, (3) alat perhubungan di dalam keluarga dan masyarakat Jawa, dan (4) sarana pengembangan serta pendukung kebudayaan daerah.

Menurut Sasangka (1991: 58), tingkat tutur Bahasa Jawa pada prinsipnya hanya ada dua macam, yaitu tingkat tutur ngoko dan krama. Beberapa ahli bahasa Jawa membedakan tingkat tutur bahasa Jawa ada bermacam-macam. Soepomo Poedjasoedarma, misalkan membedakan tingkat tutur bahasa Jawa menjadi tingkat tutur krama, madya, dan ngoko.

Sedangkan menurut Ki Padmosusastra (dalam Sudaryanto, 1996:
98) tingkat tutur bahasa Jawa yang sebutannya unggah-ungguhing basa, yang sering diikuti oleh ahli bahasa hingga kini, konsep pembagian tingkat tutur secara sistematis.

Sedangkan Poerbatjaraka (dalam Sudaryanto, 1996: 101) menyatakan bahwa secara prinsip tingkat tutur bahasa Jawa terbagi empat, yaitu: ngoko, krama , ngoko-krama, krama-ngoko

Tingkat ngoko adalah tingkat tutur yang menunjukkan kesopanan rendah. Ragam tutur ini digunakan oleh mereka yang merasa sudah akrab, dan mereka yang merasa dirinya derajatnya lebih tinggi, (Sasangka, 1991: 58), serta orang tua kepada orang muda. Sedangkan ragam tindak tutur krama digunakan menghormati, misalkan; orang muda pada orang tua, bawahan kepada atasannya, siswa pada gurunya, dan sebagainya.

Pengajaran bahasa yang lazim digunakan adalah dengan tiga cara, yaitu (1) menjelaskan sesuatu pada siswa; (2) melatih sesuatu pada siswa; dan (3) melibatkan siswa di dalam suatu kegiatan berbahasa. Apabila guru menjelaskan sesuatu itu menuntut siswa untuk menghafalkan. Guru yang melatihkan sesuatu menuntut siswa untuk mengulang-ulang mengerjakan bahan ajar. Guru yang melibatkan siswa untuk melakukan kegiatan berbahasa hanyalah berperan sebagai fasilitator, pembuka jalan saja dalam kegiatan tertentu (Purwo, 1997: 19-20).

Lebih lanjut Purwo (1997 : 20-21) menjelaskan bahwa keterampilan berbahasa bukan semata-mata diajarkan melalui uraian atau penjelasan sematamata. Siswa tidak dapat memperoleh keterampilan berbahasa dengan duduk dan mendengarkan keterangan guru dan mencatat apa yang didengarkan, dan latihan-latihan secara bertubi-tubi saja juga tidaklah cukup.

Keterampilan berbicara merupakan salah satu dari keterampilan berbahasa yang produktif. Suyatno (2004: 113 - 
121) menjelaskan beberapa teknik untuk meningkatkan kemampuan berbicara diantaranya; wawancara, cerita berpasangan, pidato tanpa teks, pidato dengan teks, mengomentari film/sinetron/cerpen/novel, debat, menjadi pembawa acara, memimpin rapat, menerangkan obat/makanan/minuman/benda lainnya, bermain peran, info berantai, dan cerita berantai.

Dari uraian tersebut di atas dapat disimpulkan bahwa kemampuan berbahasa Jawa dalam penelitian ini adalah kemampuan berbicara/micara menggunakan bahasa Jawa dengan unggah-ungguh yang tepat, yaitu penggunaan bahasa Jawa ragam ngoko dan ragam krama. Dalam penelitian ini kemampuan bahasa mencakup pada bahasa Jawa ragam krama.

Metode pembelajaran bermain peran lebih banyak menuntut aktivitas siswa dalam pembelajaran. Di samping itu metode pembelajaran bermain peran adalah metode pembelajaran yang dilakukan dengan cara permainan kelompok . Metode bermain peran untuk proses pembelajaran kemampuan berbahasa sesuai dengan kompetensi dasar yang diharapkan, juga bermuatan nilai-nilai pendidikan karakter. Nilainilai pendidikan karakter yang akan diterapkan dalam model pembelajaran bermain peran ini didasarkan pada 18 nilai yang ditetapkan oleh Kemdiknas. Secara ekplisit nilai karakter: kerja sama, komunikatif, dan percaya diri.

Berdasarkan kerangka berpikir tersebut, peneliti berasumsi bahwa: 1) pemanfaatan metode pembelajaran bermain peran untuk aspek kemampuan berbahasa diduga meningkatkan aktivitas belajar peserta didik, 2) metode pembelajaran bermain peran diduga efektif untuk merubah perilaku belajar peserta didik dalam pembelajaran kemampuan berbahasa (wicara), dan 3) pemanfaatan metode bermain peran diduga efektif meningkatkan kemampuan berbahasa peserta didik kelas 6 SD 5 Hadipolo Kecamatan Jekulo Kabupaten Kudus semester 1 tahun pelajaran 2014/2015.

\section{METODE PENELITIAN}

Penelitian dengan judul Metode Bermain Peran sebagai Upaya

Meningkatkan Kemampuan Berbahasa Jawa Peserta Didik Kelas 6 SD 5 Hadipolo Kecamatan Jekulo Kabupaten Kudus semester 1 tahun pelajaran 2014/2015, dilakukan pada Peserta Didik Kelas 6 SD 5 Hadipolo Kecamatan Jekulo Kabupaten Kudus semester 1 tahun pelajaran 2014/2015 yang berjumlah 19 peserta didik, 8 laki-laki dan 11 perempuan.

Penelitian tindakan kelas ini dilaksanakan di SD 5 Hadipolo Kecamatan Jekulo Kabupaten Kudus. Penelitian ini dilaksanakan pada minggu ketiga bulan Juli sampai dengan bulan oktober 2014.

Subjek penelitian dalam penelitian ini adalah peserta didik kelas 6 SD 5 Hadipolo Kecamatan Jekulo Kabupaten Kudus semester 1 tahun pelajaran 2014/2015. Dalam penelitian ini peneliti berkolaborasi dengan satu guru yang mengajar Bahasa Jawa lain untuk mengamati pelaksanaan penelitian.

Dalam menjawab permasalahan, ada beberapa faktor yang akan diselidiki, yaitu: 1) siswa, memperhatikan minat, keberanian, partisipasi, dan hasil pembelajaran, 2) pembelajaran, mengamati efektivitas penggunaan metode bermain peran dalam meningkatkan kemampuan berbahasa Jawa siswa.

Penelitian tindakan kelas ini mengacu model penelitian yang dikembangkan Kemmis dan Taggart (dalam Aqib, 2006: 22). Rencana tindakan dalam penelitian ini terdiri dari 3 siklus. Masing-masing siklus adalah saling berkaitan.

Adapun gambaran pelaksanaan
siklus adalah sebagai 
perencanaan (plan), 2) pelaksanaan dan pengamatan (action dan observasi), 3. Refleksi,guru merefleksikan proses pembelajaran dengan pengamat, menyimpulkan dan menilai hasil kerja siswa pada siklus 1 , dalam siklus pertama apabila dirasa masih kurang maksimal maka akan dilanjutkan pada siklus 2, pelaksanaan siklus 2 tetap melalui tiga tahapan yaitu perencanaan, pelaksanaan dan observasi, dan refleksi, jika hasil masih juga belum memuaskan maka dilaksanakan siklus 3 dengan tahapan yang sama.

Setelah kegiatan pembelajaran selesai, guru membagikan lembar angket kepada siswa untuk mengetahui kesan, tanggapan dan saran terhadap materi, cara mengajar, dan teknik yang baru saja digunakan guru dalam proses pembelajaran berbicara berbahasa Jawa dengan menggunakan metode Bermain Peran.

Wawancara dilakukan untuk mengetahui tanggapan siswa tentang pembelajaran berbicara berbahasa Jawa. Wawancara dilakukan di luar jam pelajaran. Wawancara dilakukan kepada siswa yang mendapat nilai rendah, sedang dan tinggi. Peneliti menanyakan tentang materi yang digunakan oleh guru dalam kegiatan pembelajaran, serta menanyakan kesulitan dan penyebab kesulitan yang dihadapi siswa.

Dalam penelitian tindakan kelas ini, peneliti melakukan analisis hasil data, hasil observasi, hasil jurnal, dan hasil wawancara yang telah dilakukan. Hasil analisis ini digunakan untuk mengetahui kelebihan dan kekurangan materi pembelajaran yang dilakukan oleh peneliti dan untuk mengetahui sikap yang dilakukan oleh siswa selama proses pembelajaran. Refleksi pada siklus I dijadikan masukan dalam menentukan langkah pada siklus II. Dengan demikian, akan dilakukan perbaikan perencanaan dan tindakan pada siklus II, sehingga hasil pembelajaran diharapkan semakin meningkat. Masalah-masalah yang menjadi kendala pada siklus I dicari pemecahannya, sedangkan kelebihankelebihanya dipertahankan dan ditingkatkan.

Variabel dalam penelitian ini ada 2, yaitu variable input dan variable output Variabel input-output pada penelitian ini adalah Kemampuan berbahasa Jawa. Tindakan yang akan dilakukan pada pembelajaran berbicara berbahasa Jawa yaitu guru membagikan teks pacelathon berbahasa Jawa sesuai dengan unggah-ungguh basa Jawa pada siswa. Setelah itu guru memberikan soal apersepsi pada siswa, dan guru mencatat siswa yang mengalami kesulitan dalam berbicara berbahasa Jawa. Target yang diharapkan adalah dengan metode bermain peran, kemampuan berbahasa Jawa siswa dapat bertambah.

Menurut Zuriah (2003), ada 5 jenis instrumen yang digunakan dalam penelitian tindakan. Diantaranya observasi, wawancara, catatan lapangan, angket, dan dokumentasi. Dalam penelitian ini instrumen yang digunakan meliputi: (1) observasi, (2) wawancara, dan (3) dokumentasi.

Obserasi diartikan sebagai
pengamatan dan pencatatan secara sistematik terhadap gejala yang tampak pada objek penelitian (Zuriah, 2003). Ada dua jenis observasi yang dilakukan, diantaranya: (a) observasi langsung, yaitu observasi yang dilakukan dimana observer berada bersama objek yang diselidiki, dan (b) obsevasi tidak langsung, yaitu observasi atau pengamatan yang dilakukan tidak pada saat berlangsungnya suatu peristiwa yang akan diteliti. Dengan menggunakan teknik ini, melakukan catatan terhadap hasil observasi dengan menggunakan daftar cek (chek list).

Dalam penelitian yang dilakukan secara kolaboratif yang melibatkan guru mata pelajaran bahasa Jawa yang berfungsi sebagai pengamat di kelas ini menggunakan instrumen sebagai berikut : 1) lembar wawancara untuk mengetahui 
minat peserta didik, 2) lembar observasi untuk peserta didik, untuk memonitor proses, 3) lembar observasi untuk guru, 4) lembar evaluasi/penilaian.

Instrumen penelitian yang digunakan untuk mengumpulkan data dalam penelitian ini berupa tes dan non tes. Tes yang digunakan untuk mengumpulkan data tentang kesulitan berbicara berbahasa Jawa berupa tes berbicara berbahasa Jawa.

Tes yang digunakan untuk mengukur keterampilan berbicara berbahasa Jawa siswa berupa teks pacelathon yang telah disiapkan oleh peneliti. Tingkat kesulitan dijadiakan pedoman untuk memperbaiki strategi pembelajaran berikutnya.

Teknik dan alat pengumpulan data dalam penelitian tindakan kelas ini meliputi: observasi, wawancara, angket, tes dan studi dokumentasi.

Dalam penelitian tindakan kelas ini, observasi yang digunakan adalah observasi partisipan dengan derajat keterlibatan pemeran serta sebagai pengamat, artinya pengamat tidak sepenuhnya sebagai pemeran serta tetapi masih melakukan fungsi pengamatan atau pengamat pura-pura menjadi anggota kelompok yang diamati.

Hal tersebut dilakukan dengan pertimbangan : (1) agar proses

\begin{tabular}{|c|c|c|c|c|}
\hline No & Pernyataan & $\mathrm{Jml}$ & $\%$ & Ket \\
\hline 1 & Berminat & 6 & 31,58 & \multirow{4}{*}{$\begin{array}{l}\text { Data } \\
\text { diper } \\
\text { oleh } \\
\text { dari } \\
\text { wawa } \\
\text { ncara }\end{array}$} \\
\hline 2 & $\begin{array}{c}\text { Tidak } \\
\text { berminat }\end{array}$ & 13 & 68,42 & \\
\hline 3 & Berani & 5 & 26,32 & \\
\hline 4 & $\begin{array}{l}\text { Tidak } \\
\text { berani }\end{array}$ & 14 & 73,68 & \\
\hline
\end{tabular}

pengamatan tidak mengganggu kegiatan orang yang diamati; (2) peristiwa yang diamati dapat berjalan wajar; dan (3) keterbatasan waktu dan tenaga. Metode observasi ini menggunakan penginderaaan langsung terhadap suatu benda, kondisi, situasi atau motivasi. Observasi dilakukan untuk memperoleh informasi mengenai tingkat motivasi siswa dalam kelompok selama mengikuti kegiatan pembelajaran.

Agar data valid dan reliabel, selama pengumpulan data dilakukan validasi data. Selama proses pengumpulan data perlu dilaksanakan dua jenis validasi data. Adapun jenisnya adalah validasi proses dan hasil belajar.

\section{HASIL PENELITIAN DAN PEMBAHASANNYA}

Berdasarkan penelitian tindakan yang dilakukan oleh peneliti, dapat diuraikan data-data dan hasil seperti di bawah ini.

Minat belajar siswa kelas 6 SD 5 Hadipolo Kecamatan Jekulo Kabupaten Kudus semester 1 tahun pelajaran 2014/2015 dalam belajar bahasa Jawa masih rendah. Berdasarkan angket $68,42 \%$ atau 13 siswa kelas 6 menganggap belajar bahasa Jawa tidak penting. Namun demikian 6 siswa atau $31,58 \%$ siswa lainnya berminat mempelajari bahasa Jawa karena sebagai tanggung jawab orang Jawa.

Berdasarkan angket 73,68\% atau 14 siswa tidak berani berbahasa Jawa krama dengan guru atau orang tuanya karena takut salah dan tidak tahu apa bahasa Jawa halusnya atau kurangnya kosakata. Sedangkan 26,32\% siswa berani berbahasa Jawa terutama ragam krama meskipun banyak kekurangtepatan penggunaan unggah-ungguh bahasanya.

Data hasil catatan observasi tersebut bila didistribusikan dalam tabel adalah sebagai berikut:

\section{Tabel 4.1}

\section{Minat Dan Keberanian Berbahasa Jawa}

Aktivitas siswa yang diamati dalam penelitian ini adalah aktivitas dalam kelas. Berdasarkan pada observasi dan catatan peneliti dalam penelitian tindakan ini, diperoleh data aktivitas siswa sebagai berikut. 
Tabel 4.2

Prosentase Pengelompokan Aktivitas

Siswa Kelas 6

SD 5 Hadipolo Kecamatan Jekulo

Kabupaten Kudus dalam Belajar Bahasa

Jawa

\begin{tabular}{|c|c|c|}
\hline Tingkatan & Frekuensi & Prosentase \\
\hline Tinggi & 6 & $31.58 \%$ \\
\hline Sedang & 10 & $52.63 \%$ \\
\hline Kurang & 3 & $15.79 \%$ \\
\hline
\end{tabular}

Prestasi hasil belajar yang didapatkan oleh siswa kelas 6 SD 5 Hadipolo Kecamatan Jekulo Kabupaten Kudus semester 1 tahun pelajaran 2014/2015 dalam belajar mata pelajaran bahasa Jawa dalam materi berbicara adalah sebagai berikut:

Tabel 4.3

Prosentase Hasil Belajar Peserta Didik Kelas 6

SD 5 Hadipolo Kecamatan Jekulo

Kabupaten Kudus Semester I Tahun

Pelajaran 2014/2015

dalam Berbicara Bahasa Jawa

Berdasarkan pada angket, observasi dan catatan peneliti sebelum kegiatan penelitian berlangsung didapatkan temuan sebagai berikut: (1) terlihat ada minat belajar siswa dalam kegiatan belajar mengajar masih rendah, (2) keaktifan siswa dalam mengikuti pelajaran bahasa Jawa sedang, (3) kegiatan belajar terkesan hidup dan berjalan, tetapi didominasi oleh siswa yang pandai.

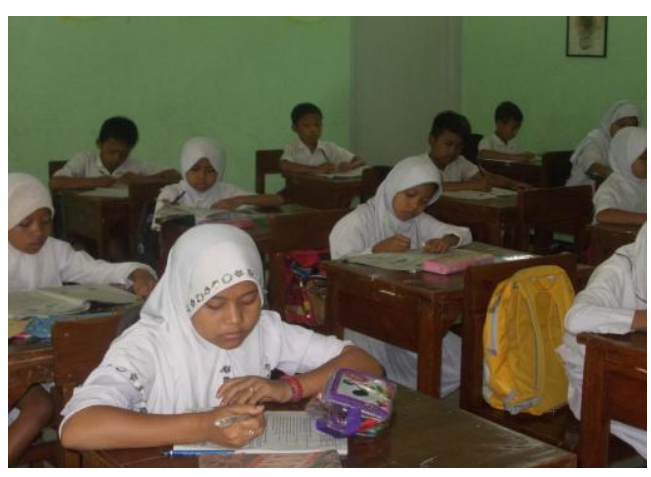

sabtu tanggal 26 Juli 2014. Minat belajar siswa kelas 6 SD 5 Hadipolo Kecamatan Jekulo Kabupaten Kudus semester 1 tahun pelajaran 2014/2015 setelah dilakukan pembelajaran berbicara bahasa Jawa dengan metode bermain peran didapatkan hasil sebagai berikut: $73,68 \%$ atau 14 siswa kelas 6 menganggap belajar bahasa Jawa penting. Namun demikian 5 (26,32\%) siswa lainnya masih menyatakan kekurangminatan mempelajari bahasa Jawa karena merasa sulit.

Data hasil catatan observasi tersebut bila didistribusikan dalam tabel adalah sebagai berikut:

Tabel 4.4

Minat dan Keberanian Berbahasa Jawa

\begin{tabular}{|c|c|c|c|c|}
\hline No. & Pernyataan & $\mathrm{Jml}$ & $\%$ & Ket \\
\hline 1 & Berminat & 14 & 73,68 & \\
\hline 2 & $\begin{array}{c}\text { Tidak } \\
\text { berminat }\end{array}$ & 5 & 26,32 & \\
\hline 3 & Berani & 3 & 15,79 & \\
\hline
\end{tabular}

Data

\begin{tabular}{|c|c|c|c|c|}
\hline \multirow{2}{*}{$\begin{array}{l}\mathrm{N} \\
\mathrm{o} .\end{array}$} & \multirow{2}{*}{ Nilai } & \multicolumn{2}{|c|}{ Frekwensi } & \multirow{2}{*}{$\begin{array}{l}\text { Katingeraleh } \\
\text { Prestdari } \\
\text { Betajancara }\end{array}$} \\
\hline & & $\mathrm{Jml}$ & $\%$ & \\
\hline 1 & $81-100$ & 2 & 10,53 & Baik \\
\hline 2 & $61-80$ & 15 & 78,94 & $\begin{array}{l}\text { Sedserva } \\
\text { Sedang }\end{array}$ \\
\hline \multirow[t]{2}{*}{3} & $50-60$ & 2 & 10,53 & Kurang \\
\hline & Total & 19 & 100 & \\
\hline 4 & $\begin{array}{l}\text { Tida } \\
\text { beran }\end{array}$ & & , & \\
\hline
\end{tabular}

Dari tabel tersebut, membuktikan bahwa minat belajar dan keberanian siswa kelas 6 SD 5 Hadipolo Kecamatan Jekulo Kabupaten Kudus semester 1 tahun pelajaran 2014/2015 dalam berbahasa Jawa tergolong sedang 
Aktivitas siswa dalam mengikuti materi berbicara bahasa Jawa terdapat peningkatan, seperti tergambar dalam tabel berikut:

Tabel 4.5

Prosentase Pengelompokan Aktivitas Peserta Didik Kelas 6

SD 5 Hadipolo Kecamatan Jekulo Kabupaten Kudus Semester I Tahun

Pelajaran 2014/2015 dalam Belajar Bahasa Jawa

\begin{tabular}{|c|c|c|}
\hline Tingkat & Frekuensi & Prosentase \\
\hline Tinggi & 9 & $47.36 \%$ \\
\hline Sedang & 8 & $42.11 \%$ \\
\hline Kurang & 2 & $10,52 \%$ \\
\hline
\end{tabular}

Prestasi hasil belajar yang didapatkan oleh siswa kelas 6 SD 5 Hadipolo Kecamatan Jekulo Kabupaten Kudus semester 1 tahun pelajaran 2014/2015 , dalam berbicara bahasa Jawa setelah penggunaan metode bermain peran adalah sebagai berikut:

Tabel 4.6

Prosentase Hasil Belajar Peserta Didik kelas 6 SD 5 Hadipolo Kecamatan Jekulo

Kabupaten Kudus semester 1 tahun pelajaran 2014/2015 dalam Berbicara

Bahasa Jawa

\begin{tabular}{|c|c|c|c|c|}
\hline \multirow{2}{*}{$\begin{array}{c}\text { N } \\
\text { o. }\end{array}$} & \multirow{2}{*}{ Nilai } & \multicolumn{2}{|c|}{ Frekwensi } & \multirow{2}{*}{$\begin{array}{c}\text { Katagori } \\
\text { Prestasi } \\
\text { Belajar }\end{array}$} \\
\cline { 3 - 4 } & & Jml & $\%$ & Baik \\
\hline 1 & $81-100$ & 7 & 37,85 & Sedang \\
2 & $61-80$ & 10 & 52,63 & Kurang \\
3 & $50-60$ & 2 & 10,52 & Kun \\
\hline & Total & 19 & $100 \%$ & \\
\hline
\end{tabular}

Siklus 2 dilaksanakan pada hari sabtu tanggal 16 Agustus 2014. Setelah dilakukan perencanaan ulang berdasarkan refleksi siklus 1 didapatkan hasil sebagai berikut: Minat belajar siswa kelas 6 SD 5 Hadipolo Kecamatan Jekulo
Kabupaten Kudus semester 1 tahun pelajaran 2014/2015 dalam siklus 2 didapatkan hasil sebagai berikut :

Tabel 4.7

Minat dan Keberanian Berbahasa Jawa

\begin{tabular}{|c|c|c|c|c|}
\hline $\mathrm{N}$ & Pernyataan & $\mathrm{Jml}$ & $\%$ & Ket \\
\hline 1 & \multirow{3}{*}{$\begin{array}{c}\text { Berminat } \\
\text { Tidak } \\
\text { berminat } \\
\text { Berani }\end{array}$} & \multirow{2}{*}{$\begin{array}{c}16 \\
3\end{array}$} & 84,22 & \multirow{4}{*}{$\begin{array}{c}\text { Data } \\
\text { diperol } \\
\text { eh dari } \\
\text { wawan } \\
\text { cara } \\
\text { dan } \\
\text { observ } \\
\text { asi }\end{array}$} \\
\hline 2 & & & 15,78 & \\
\hline 3 & & 15 & 78,95 & \\
\hline 4 & $\begin{array}{l}\text { Tidak } \\
\text { berani }\end{array}$ & 4 & 21,05 & \\
\hline
\end{tabular}

Aktivitas siswa dalam mengikuti materi berbicara bahasa Jawa, seperti terlihat dalam tabel berikut:

Tabel 4.8

Prosentase Pengelompokan Aktivitas Peserta Didik Kelas 6 SD 5 Hadipolo Kecamatan Jekulo Kabupaten Kudus Semester I Tahun Pelajaran 2014/2015 dalam Belajar Bahasa Jawa

\begin{tabular}{|c|c|c|}
\hline Tingkat & Frekuensi & Prosentase \\
\hline Tinggi & 14 & $73.68 \%$ \\
\hline Sedang & 4 & $21,05 \%$ \\
\hline Kurang & 1 & $5.27 \%$ \\
\hline \multicolumn{2}{|c|}{ Prestasi } & hasil belajar yang
\end{tabular}
didapatkan oleh siswa kelas 6 SD 5 Hadipolo Kecamatan Jekulo Kabupaten Kudus semester 1 tahun pelajaran 2014/2015 setelah penggunaan metode bermain peran adalah sebagai berikut:

Tabel 4.9

Prosentase Hasil Belajar Peserta Didik Kelas 6 
SD 5 Hadipolo Kecamatan Jekulo Kabupaten Kudus Semester I Tahun Pelajaran 2014/2015

dalam Berbicara Bahasa Jawa

\begin{tabular}{|c|c|c|c|c|}
\hline \multirow{2}{*}{$\begin{array}{c}\text { N } \\
\text { o. }\end{array}$} & \multirow{2}{*}{ Nilai } & \multicolumn{2}{|c|}{ Frekwensi } & \multirow{2}{*}{$\begin{array}{c}\text { Katagori } \\
\text { Prestasi } \\
\text { Belajar }\end{array}$} \\
\cline { 3 - 4 } & & Jml & $\%$ & \\
\hline 1 & $81-$ & 14 & 78,94 & Baik \\
2 & 100 & 3 & 15,79 & Sedang \\
3 & $61-80$ & 2 & 5,37 & Kurang \\
& $50-60$ & & & \\
\hline c & Total & 19 & $100 \%$ & \\
\hline
\end{tabular}

Siklus 3 dilaksanakan pada hari sabtu tanggal 23 Agustus 2014. Minat belajar siswa kelas 6 SD 5 Hadipolo Kecamatan Jekulo Kabupaten Kudus semester 1 tahun pelajaran 2014/2015 dalam siklus 2 didapatkan hasil sebagai berikut :

Tabel 4.10

Minat dan Keberanian Berbahasa Jawa

\begin{tabular}{|c|c|c|c|c|}
\hline No & $\begin{array}{c}\text { Pernyata } \\
\text { an }\end{array}$ & $\mathrm{Jml}$ & $\%$ & $\begin{array}{l}\text { Keter } \\
\text { angan }\end{array}$ \\
\hline 1 & $\begin{array}{c}\text { Bermina } \\
\mathrm{t}\end{array}$ & 17 & 89,48 & $\begin{array}{l}\text { Data } \\
\text { dipero }\end{array}$ \\
\hline 2 & $\begin{array}{c}\text { Tidak } \\
\text { berminat }\end{array}$ & 2 & 10,52 & $\begin{array}{l}\text { leh } \\
\text { dari }\end{array}$ \\
\hline 3 & Berani & 18 & 94,74 & wawa \\
\hline 4 & $\begin{array}{l}\text { Tidak } \\
\text { berani }\end{array}$ & 1 & 5,26 & $\begin{array}{c}\text { dan } \\
\text { obser } \\
\text { vasi }\end{array}$ \\
\hline
\end{tabular}

Aktivitas siswa dalam mengikuti materi berbicara bahasa Jawa, seperti terlihat dalam tabel berikut:

Tabel 4.11

Prosentase Pengelompokan Peserta Didik Kelas 6

SD 5 Hadipolo Kecamatan Jekulo Kabupaten Kudus Semester I Tahun Pelajaran 2014/2015 dalam Belajar Bahasa Jawa

\begin{tabular}{|c|c|c|}
\hline Tingkatan & Frekuensi & Prosentase \\
\hline Tinggi & 17 & $89,48 \%$ \\
\hline Sedang & 1 & $5,26 \%$ \\
\hline Kurang & 1 & $5,26 \%$ \\
\hline
\end{tabular}

Prestasi hasil belajar yang didapatkan oleh siswa kelas 6 SD 5 Hadipolo Kecamatan Jekulo Kabupaten Kudus semester 1 tahun pelajaran 2014/2015 dalam belajar berbahasa Jawa dengan metode bermain peran dalam siklus 3 adalah sebagai berikut: 
Tabel 4.12

Prosentase Hasil Belajar Peserta Didik Kelas 6

SD 5 Hadipolo Kecamatan Jekulo

Kabupaten Kudus Semester I Tahun

Pelajaran 2014/2015

dalam Berbicara Bahasa Jawa

\begin{tabular}{|c|c|c|c|c|}
\hline \multirow{2}{*}{$\begin{array}{l}\text { N } \\
\text { o }\end{array}$} & \multirow{2}{*}{ Nilai } & \multicolumn{2}{|c|}{ Frekuensi } & \multirow{2}{*}{$\begin{array}{c}\text { Katagori } \\
\text { Prestasi } \\
\text { Belajar }\end{array}$} \\
\cline { 3 - 4 } & & Jml & $\%$ & Baik \\
\hline 1 & $81-100$ & 17 & 89,48 & Sedang \\
2 & $61-80$ & 1 & 5,26 & Kurang \\
3 & $50-60$ & 1 & 5,26 & Kun \\
\hline & Total & 19 & 100 & \\
\hline
\end{tabular}

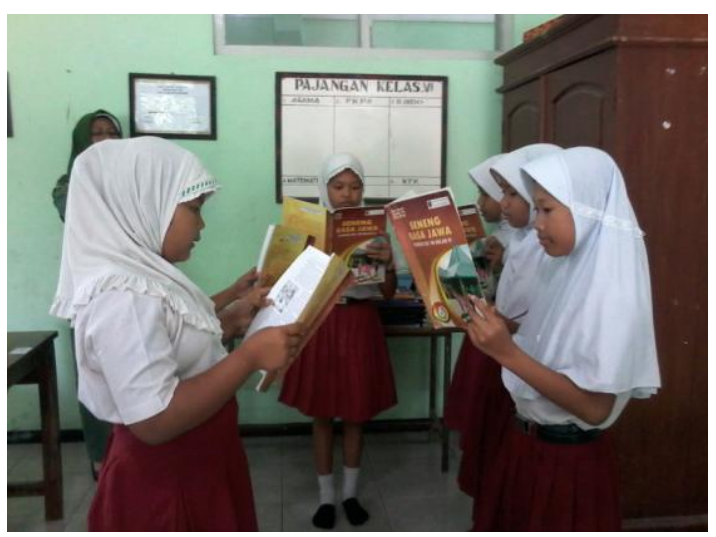

Pembelajaran dengan bermain peran

Pembahasan

Pada hakikatnya pembelajaran bahasa di sekolah adalah menjadikan siswa yang terampil berbahasa. Kendala yang dihadapi di lapangan adalah siswa mengerti ilmu bahasanya tetapi lemah dalam berbahasa itu sendiri. Demikian halnya dengan bicara bahasa Jawa. Siswa mengalami banyak permasalahan dengan berkomunikasi bahasa Jawa dengan ragam krama.

Kesulitan penggunaan bahasa Jawa khususnya ragam krama disebabkan lingkugan hidup dan lingkungan belajar siswa yang sudah menggunakan bahasa Indonesia sebagai bahasa pergaulan. Namun demikian bahasa Jawa ragam ngoko masih digunakan sebagai bahasa ibu.
Penggunaan metode bermain peran dalam pembelajaran berbicara bahasa Jawa memiliki dampak yang positif. Dengan metode ini dapat meningkatkan minat dan keberanian siswa dalam berbicara dengan menggunakan bahasa Jawa. Seperti dalam tabel berikut :

Tabel 4.13

Rekapitulasi Minat dan Keberanian Berbahasa Jawa

Peserta Didik Kelas 6

SD 5 Hadipolo Kecamatan Jekulo

Kabupaten Kudus Semester I Tahun Pelajaran 2014/2015

\begin{tabular}{|c|c||c||c||c||c|}
\hline $\begin{array}{c}\mathrm{N} \\
\mathrm{o}\end{array}$ & $\begin{array}{c}\text { Pernya } \\
\text { taan }\end{array}$ & $\begin{array}{c}\text { Pra } \\
\text { Siklus }\end{array}$ & $\mathrm{S} 1$ & $\mathrm{~S} 2$ & $\mathrm{~S} 3$ \\
\hline \multirow{2}{*}{1} & $\begin{array}{c}\text { Bermi } \\
\text { nat }\end{array}$ & $\begin{array}{c}31,58 \\
\%\end{array}$ & $\begin{array}{c}73,6 \\
8 \%\end{array}$ & $\begin{array}{c}84,2 \\
2 \%\end{array}$ & $\begin{array}{c}89, \\
48 \\
\%\end{array}$ \\
\hline \multirow{2}{*}{2} & $\begin{array}{c}\text { Tidak } \\
\text { bermin } \\
\text { at }\end{array}$ & $\begin{array}{c}68,42 \\
\%\end{array}$ & $\begin{array}{c}26,3 \\
2 \%\end{array}$ & $\begin{array}{c}15,7 \\
8 \%\end{array}$ & $\begin{array}{c}10, \\
52 \\
\%\end{array}$ \\
\hline \hline \multirow{2}{*}{3} & Berani & $\begin{array}{c}26,32 \\
\%\end{array}$ & $\begin{array}{c}15,7 \\
9 \%\end{array}$ & $\begin{array}{c}76,9 \\
5 \%\end{array}$ & $\begin{array}{c}94 \\
74 \\
\%\end{array}$ \\
\hline 4 & $\begin{array}{c}\text { Tidak } \\
\text { berani }\end{array}$ & $\begin{array}{c}73,68 \\
\%\end{array}$ & $\begin{array}{c}84,2 \\
1 \%\end{array}$ & $\begin{array}{c}21,0 \\
5 \%\end{array}$ & $\begin{array}{c}5,2 \\
6 \%\end{array}$ \\
\hline
\end{tabular}

Dari tabel di atas nampak bahwa keberminatan siswa terhadap bahasa terjadi peningkatan yang signifikan. Dengan demikian hipotesis kedua diterima yaitu metode pembelajaran bermain peran efektif untuk merubah perilaku belajar peserta didik kelas $6 \mathrm{SD}$ Negeri 5 Hadipolo Kecamatan Jekulo Kabuapten Kudus semester 1 tahun pelajaran 2014/2015 dalam pembelajaran kemampuan berbahasa (wicara). Apabila sebelum dilakukan penelitian dengan metode bermain peran siswa yang berminat untuk berbicara dengan bahasa Jawa ragam krama hanya $31,58 \%$ atau hanya 6 siswa, setelah dilakukan penelitian tindakan kelas dengan menggunakan metode bermain peran jumlah siswa yang berminat berkomunikasi dengan menggunakan 
bahasa Jawa menjadi $89,48 \%$ atau 19 siswa. Hal ini menunjukkan adanya peningkatan 57,9\%. Peningkatan ini dikarenakan dengan metode bermain peran yang mengedepankan permainan menjadikan belajar lebih menyenangkan dan belajar berbicara bahasa Jawa menjadi lebih mudah dan mengena pada dunia anak-anak. Sedangkan 2 siswa yang kurang berminat memelajari bahasa Jawa karena komunitas pergaulan dikeluargannya menggunakan bahasa Indonesia.

Keberanian siswa dalam berbicara dengan menggunakan bahasa Jawa juga mengalami peningkatan yang signifikan. Pada fase sebelum diadakan perlakuan keberanian berbahasa Jawa siswa kelas 5 sebesar 26,32\% (5 siswa), setelah diadakan 3 siklus tindakan keberanian siswa meningkat menjadi $94,74 \%$ (18 siswa). Berarti terdapat peningkatan $68,42 \%$. Peningkatan keberanian ini disebabkan adanya arena berlatih yang seolah-olah dalam kehidupan nyata. Dengan bermain peran seolah-olah siswa seperti dalam kehidupan nyata.

Tingkat keaktifan siswa dalam pembelajaran siswa sebelum dan setelah diadakan tindakan seperti pada tabel berikut :

Tabel 4.14

Rekapitulasi Aktivitas Peserta Didik Kelas 6

SD 5 Hadipolo Kecamatan Jekulo

Kabupaten Kudus Semester I Tahun

Pelajaran 2014/2015 dalam KBM Bahasa Jawa

\begin{tabular}{|c|c|c|c|c|c|}
\hline $\begin{array}{c}\mathrm{N} \\
\mathrm{o}\end{array}$ & $\begin{array}{c}\text { Ting } \\
\text { katan }\end{array}$ & $\begin{array}{c}\text { Pra } \\
\text { Siklus }\end{array}$ & S 1 & S 2 & S 3 \\
\hline 1 & $\begin{array}{c}\text { Ting } \\
\text { gi }\end{array}$ & $\begin{array}{c}31,58 \\
\%\end{array}$ & $\begin{array}{c}47,3 \\
6 \%\end{array}$ & $\begin{array}{c}73, \\
68 \\
\%\end{array}$ & $\begin{array}{c}89,48 \\
\%\end{array}$ \\
\hline 2 & $\begin{array}{c}\text { Seda } \\
\text { ng }\end{array}$ & $\begin{array}{c}52,63 \\
\%\end{array}$ & $\begin{array}{c}42,1 \\
1 \%\end{array}$ & $\begin{array}{c}21, \\
05 \\
\%\end{array}$ & $\begin{array}{c}5,26 \\
\%\end{array}$ \\
\hline 3 & $\begin{array}{c}\text { Kura } \\
\text { ng }\end{array}$ & $\begin{array}{c}15,79 \\
\%\end{array}$ & $\begin{array}{c}10,5 \\
2 \%\end{array}$ & $\begin{array}{c}5,2 \\
7 \%\end{array}$ & $\begin{array}{c}5,26 \\
\%\end{array}$ \\
\hline
\end{tabular}

Dari tabel keaktifan siswa nampak sebelum perlakuan hanya 6 siswa $(31,58 \%)$ saja yang beraktifitas tinggi, rata-rata aktifitas selama pelajaran berlangsung sedang dan cenderung pasif. Hal tersebut karena minat dan keberanian yang rendah. Setelah diadakan perlakuan siklus 3 kali nampak adanya peningkatan sebesar 57,90\% menjadi $89,48 \%$ atau 17 siswa dari 19 siswa sudah berperan aktif selama pembelajaran. Dengan perolehan data rekapitulasi tersebut, maka hipotesis pertama diterima, yaitu pemanfaatan metode pembelajaran bermain peran untuk aspek kemampuan berbahasa dapat meningkatkan aktivitas belajar peserta didik kelas 6 SD 5 Hadipolo Kecamatan Jekulo Kabupaten Kudus semester 1 tahun pelajaran 2014/2015.

Tabel 4.15

Rekapitulasi Pretasi Belajar Peserta Didik Kelas 6

SD 5 Hadipolo Kecamatan Jekulo

Kabupaten Kudus Semester I Tahun Pelajaran 2014/2015

\begin{tabular}{|c|c|c|cc|c|}
\hline No & Nilai & $\begin{array}{c}\text { Pra } \\
\text { Siklus }\end{array}$ & S 1 & S 2 & S 3 \\
\hline 1 & $\begin{array}{c}81- \\
100\end{array}$ & $\begin{array}{c}10,53 \\
\%\end{array}$ & $\begin{array}{c}37,8 \\
5 \%\end{array}$ & $\begin{array}{c}78,9 \\
4 \%\end{array}$ & $\begin{array}{c}89 \\
48 \\
\%\end{array}$ \\
\hline 2 & $\begin{array}{c}61- \\
80\end{array}$ & $\begin{array}{c}78,94 \\
\%\end{array}$ & $\begin{array}{c}52,6 \\
3 \%\end{array}$ & $\begin{array}{c}15,7 \\
9 \%\end{array}$ & $\begin{array}{c}5,2 \\
6 \%\end{array}$ \\
\hline 3 & $50-$ & $\begin{array}{c}10,53 \\
\%\end{array}$ & $\begin{array}{c}10,5 \\
2 \%\end{array}$ & $\begin{array}{c}5,37 \\
\%\end{array}$ & $\begin{array}{c}5,2 \\
6 \%\end{array}$ \\
\hline
\end{tabular}

Dari hasil pretest kemampuan berbahasa Jawa hanya 2 siswa yang memperoleh hasil lebih dari 80 sesuai dengan harapan peneliti. Sedangkan ratarata nilai siswa memperoleh nilai 61 80 yaitu 78,94\%. Terdapat 2 siswa yang memperoleh nilai di bawah 60 .

Setelah menggunakan metode bermain peran nampak setelah siklus ke 3 perolehan nilai siswa di atas 80 mencapai $89,48 \%$ atau meningkat $78,95 \%$. Sedangkan yang memperoleh nilai di bawah 60 hanya 1 orang $(5,26 \%)$ 
dan yang memperoleh nilai 61-80 sebanyak 1 orang atau 5,26\%.

Berdasarkan data tersebut, hipotesis ketiga diterima yaitu pemanfaatan metode bermain peran efektif meningkatkan kemampuan berbahasa peserta didik kelas 6 SD 5 Hadipolo Kecamatan Jekulo Kabupaten Kudus semester 1 tahun pelajaran 2014/2015. Penggunaan metode bermain peran dalam pembelajaran berbicara bahasa Jawa memberikan dampak yang signifikan dalam peningkatan kemampuan berbahasa Jawa siswa kelas 6 SD 5 Hadipolo Kecamatan Jekulo Kabupaten Kudus semester 1 tahun pelajaran 2014/2015.

\section{PENUTUP}

Simpulan hasil penelitian ini: 1) proses pembelajaran dengan menerapkan metode bermain peran dapat meningkatkan aktivitas belajar peserta didik dalam belajar kemampuan berbahasa (wicara) peserta didik kelas 6 SD 5 Hadipolo Kecamatan Jekulo Kabupaten Kudus semester 1 tahun pelajaran 2014/2015, 2) metode bermain peran dapat meningkatkan kemampuan berbahasa (wicara) sesuai dengan undha usuk basa peserta didik kelas 6 SD 5 Hadipolo Kecamatan Jekulo Kabupaten Kudus semester 1 tahun pelajaran 2014/2015, dan 3) metode bermain peran dapat merubah perilaku belajar peserta didik yang kurang semangat menjadi semangat, kurang aktif menjadi aktif, kurang kreatif menjadi kreatif, kurang disiplin menjadi disiplin. Selain itu juga dapat menanamkan nilai-nilai pendidikan karakter kerja sama, komunikatif, dan rasa percaya diri.

Untuk mengintensifkan metode bermain peran, dapat disarankan sebagai berikut: 1) Kepada Kepala Sekolah supaya lebih banyak memberikan motivasi kepada guru dalam kegiatan belajar dan mengajar agar memanfaatkan metode yang bervariasi, khususnya metode bermain peran, 2) Kepada Guru supaya meningkatkan kemampuannya dalam kegiatan pembelajaran dan mengembangkan kreativitasnya di antaranya dengan memanfaatkan metode bermain peran agar dapat meningkatkan kemampuan berbahasa (wicara) Jawa peserta didik, dan 3) Sekolah sebagai tempat dan penyelenggara pendidikan hendaknya melengakapi fasilitas dan kebutuhan peserta didik dalam kegiatan belajar dan mengajar.

\section{DAFTAR PUSTAKA}

Nababan, P.W.J. 1986. Sosiolinguistik: Suatu Pengantar. Jakarta: Gramedia

Padmosoekotjo, S. 1958. Tata Bahasa Jawa. Djakarta: Noordhoff-Kolff N.V.

Purwo, Bambang Kaswanti. 1997. Pokok-Pokok Pengajaran Bahasa dan Kurikulum 1994. Jakarta : Pusat Pembukuan Proyek Pengembangan Buku dan Minat Baca

Sasangka, Sry Satriya Tjatur Wisnu. 1991. Prinsip Dasar Berbahasa Jawa Ngoko dan Krama. Surabaya: Citra Jaya Murti

Sudaryanto, 1996. Dari Sistem Lambang Kebahasaan Sampai Prospek Bahasa Jawa. Yogyakarta: Yayasan Studi Bahasa Jawa "Kanthil" Bekerjasama dengan Duta Wacana University Press

Sudjana, S. 2005. Metoda dan Teknik Pemelajaran Partisipatif. Bandung: Falah Production.

Sukardi mp. 1993. "Kemungkinan Bahasa Jawa Sebagai Bahasa Ilmu". Dalam Pusaran Bahasa dan Sastra Jawa. Yogyakata: Balai 
Penelitian Bahasa, Pusat

Pembinaan dan Pengembangan

Bahasa Dep P dan K Yogyakarta

Suyatno, 2004. Teknik Pembelajaran

Bahasa dan Sastra. Surabaya:

Penerbit SIC.

Widada. 1993. "Kondisi Bahasa Jawa dan Pemanfaatannya: Sekarang dan Masa Datang". Dalam Pusaran Bahasa dan Sastra Jawa. Yogyakata: Balai Penelitian Bahasa, Pusat Pembinaan dan Pengembangan Bahasa Dep P dan K Yogyakarta.

Zainal Aqib. 2006. Penelitian Tindakan Kelas: untuk guru. Bandung: CV. Yrama Widya

Zuriah, N., 2003. Penelitian Tindakan dalam Bidang Pendidikan dan Sosial. Edisi Pertama. Malang: Bayu Media Publishing 